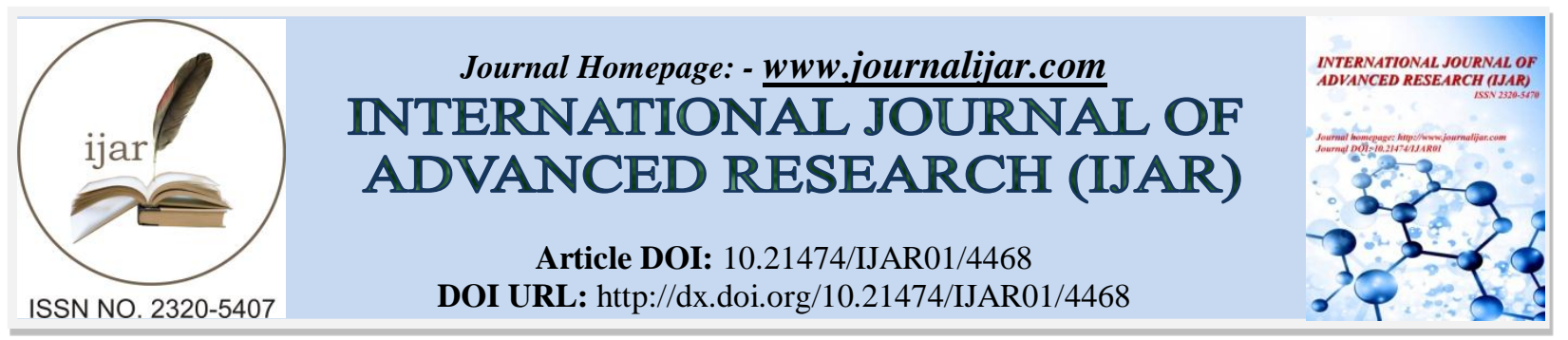

RESEARCH ARTICLE

\title{
CONSUMERS' PERCEPTIONS ON BARRIERS TOWARDS ONLINE SHOPPING.
}

Seema G Hariramani and Dr. Hemal Pandya.

1. Shri Chimanbhai Patel Institute of Business Administration, Ahmedabad.

2. S.D. School of Commerce, Gujarat University, Ahmedabad.

\section{Manuscript Info}

Manuscript History

Received: 13 April 2017

Final Accepted: 15 May 2017

Published: June 2017

Key words:-

Internet users, Online Shopping,

Difficulties, Factor Analysis,

Multiple Regression Analysis

\section{Abstract}

Daily hustle and bustle and complexities of life have left people with very little time to fulfil all the responsibilities, to do all the chores of life, to take out time for one self. There were times when customers used to reach to the company for their shopping needs. Now those times have changed, due to increased competition and technology development. With the advent of computers and internet facilities; companies have found out ways and means to reach to the customers in the form of online shopping websites. Internet has made the things easier for both. Customers shop online to save their time, energy and money but there are times when customer feels helpless due to the lack of knowledge and complex procedures which hinder the popularity of online shopping. Further, doing transactions at the arm's length is not easy. A customer faces certain difficulties while shopping online. This study is specially undertaken with the objective of knowing the barriers or difficulties that consumers face, while shopping online. A non-probability sample on convenience base of 765 internet users of online shoppers was taken by asking 15 statements on Five Point Likert Scale along with other questions in the questionnaire to record their responses. The major statistical techniques such as Chi-Square Test, Factor Analysis and Multiple Regression Analysis were applied in order to identify the factors creating hesitation towards online shopping and analysing the impact of these barriers on consumers' perception towards online shopping. Product Reliability and Technical aspects were found to be the major factors affecting the consumers' perception towards online shopping. An attempt is made to suggest some areas of improvement in the online shopping procedures in order to overcome these barriers and attract more consumers towards online shopping.

Copy Right, IJAR, 2017,. All rights reserved.

\section{Introduction:-}

Daily hustle and bustle and complexities of life have left people with very little time to fulfill all the responsibilities, to do all the chores of life, to take out time for one-self. There were times when customer used to reach to the company for their shopping needs. Now those times have changed, due to increased competition and technology development. With the advent of computers and internet facilities; companies have found out ways and means to 
reach to the customers in the form of online shopping websites. Internet has made the things easier for both. To lure the customers these websites have resorted to one-to-one marketing. Websites keep track of what people search for and then offer them customized offers. Customers shop online to save their time, energy and money but there are some times when customer feels helpless due to the lack of knowledge and complex procedures which hinder the popularity of online shopping. Further, doing transactions at the arm's length is not easy. A customer faces certain difficulties while shopping online. This study is an attempt to know exactly what difficulties customers face when actually they shop online.

\section{Literature Review:-}

To understand what problems customers face while shopping online, a virtual tour was undertaken to review the literature to find out if someone has undertaken the similar efforts. Maigan and Lukas (1997) studied on the consumer perception towards e-shopping. The study found that internet shopping involves more uncertainty and risk than traditional shopping. Consumers' unwillingness to provide their credit card information over the web has been cited as a major obstacle to online purchases. Huizingh \& Hoekstra, (2003) had explored the study on the eshopping and studied many factors that determine why customers return to a store or web-site. The study found that longer lengths of time spent online by consumers increases the likelihood of consumers revisiting a website or becoming customers by buying a product As such, designing a website in such a way as to retain customer attention and satisfaction, increases the likelihood of creating repeat customers. Another study conducted by Fayu Zheng (2006) with respondents from U.K. and China titled as "Internet Shopping And Its Impact On Consumer Behaviour" highlighted that the factors viz. the nature of Internet shopping, E-commerce website, and online security, privacy, trust and trustworthiness have impact on online shopping along with online consumer behaviour that include background, shopping motivation and decision making process. Virdi, Puri, Modi, Sehgal (2007) studied on the "pragmatic buyers or Browsers? A study of online Buying Behaviour" and their study found that online surfers demography do have a significant impact on the buying behaviour and the security concerns over the misuse of credit cards makes them cautious to shop online. The study also highlighted that spending power of the respondents varied significantly among the cities surveyed and it is proposed that the website should be made more appealing, exhaustive and should support a certificate of authenticity to generate better responses to online shopping.

Maray De Swardt (2008) in her study on "Factors influencing the choice to shop online under south African context" suggested that the reasons why some people do not shop online because of security reasons, lack of touch and unfamiliar merchants. Exploring the Influence of Online Consumers' Perception on Purchase Intention as Exemplified with an Online Bookstore (Taiwan) - a study undertaken by Lee Je Yu et al. (2009) identified the 'perceived risk' as the most important factor stopping people to shop online. Chayapa Katawetawaraks and Cheng Lu Wang (2011) in their study on 'Online Shopper Behaviour: Influences of Online Shopping Decision' investigated that major reasons that impede consumers from online shopping include unsecured payment, slow shipping, unwanted product, spam or virus, bothersome emails and technology problem. Muhammad Umar Sultan and M D Nasiruddin conducted study on 'Consumers' Attitude towards Online Shopping - Factors influencing Gotland consumers to shop online' (2011) with the objective of finding the factors that affect online shoppers of Gotland and the demography of online shoppers. Their results showed that along with other factors affecting positively, security is of important concern among online shoppers in Gotland that deters them to shop online. The study conducted by Dr. B.B Singla and Prof. Pawan Kumar (2011) on "E- Shopping: A Shift from Marketplace To Market Space" in India found that reputation of the retailer, website design, perceived ease of usefulness, perceived ease of use, offline-online integration have positive relation in maintaining customer loyalty. French researchers Maniglier Sophie and Renouf Manon (2012) studied the main factors influencing online consumer behaviour changes and found that along with other factors that push consumers shop online there are some factors that discourage them to shop online. The factors that discourage French young customers from shopping online are; trial of the product before reception, fear of dissatisfaction, bad internet connection, difficulty of exchange, no or bad customer service and order tracking.

\section{Research Methodology:- Research Objectives:-}

- To identify the major difficulties faced by the online shoppers.

- To establish the relationship between technical difficulties and customers satisfaction.

- To analyze the impact of product \& services related difficulties on satisfaction level of customers. 


\section{Research Design:-}

A conclusive research was undertaken to fulfill the objective of knowing what kind of difficulties people face when they shop online. With a population of 120 crores why online shopping has still not gained full access. A Descriptive research design was undertaken wherein 15 Likert scale statements were asked along with the other questions in a structured questionnaire.

\section{Sampling Design and Data Collection:-}

Initially 1000 internet users of the city of Ahmedabad were contacted on convenience base and asked whether they shop online. Out of them 235 people replied negatively. A structured questionnaire using some Likert Scale statements was given to the people who shop online to know what difficulties they face while shopping online. 765 usable questionnaires were received for data analysis indicating approximately $76 \%$ response rate. Initially the questionnaire was tested for its reliability on the basis of the responses from 50 respondents using Cronbach's $\alpha$ which was found to be 0.913 which indicates a fair reliability of the questionnaire.

\section{Statistical Tools:-}

- Descriptive Measures

- Factor Analysis

- Multiple Regression Analysis

Analysis and Discussions:-

Table 1:- Demographic composition of sample:

\begin{tabular}{|c|c|c|c|}
\hline Sr. No. & Demographics & Frequency & Percentage \\
\hline 1 & $\begin{array}{l}\text { Age } \\
15 \text { years to } 25 \text { years } \\
26 \text { years to } 35 \text { years } \\
36 \text { years to } 45 \text { years } \\
46 \text { years to } 55 \text { years } \\
\text { Above } 55 \text { years }\end{array}$ & $\begin{array}{l}442 \\
214 \\
72 \\
27 \\
10\end{array}$ & $\begin{array}{l}58 \\
28 \\
09 \\
04 \\
01\end{array}$ \\
\hline 2 & $\begin{array}{c}\text { Gender } \\
\text { Male } \\
\text { Female } \\
\end{array}$ & $\begin{array}{l}480 \\
285 \\
\end{array}$ & $\begin{array}{l}\mathbf{6 3} \\
\mathbf{3 7} \\
\end{array}$ \\
\hline 3 & $\begin{array}{l}\text { Education } \\
\text { SSC } \\
\text { HSC } \\
\text { Graduation } \\
\text { Post-Graduate } \\
\text { Professional Degree } \\
\end{array}$ & $\begin{array}{l}12 \\
45 \\
294 \\
293 \\
121 \\
\end{array}$ & $\begin{array}{l}02 \\
06 \\
38 \\
38 \\
16 \\
\end{array}$ \\
\hline 4 & $\begin{array}{l}\text { Occupation } \\
\text { Student } \\
\text { Service } \\
\text { Business } \\
\text { Profession } \\
\text { House wife } \\
\end{array}$ & $\begin{array}{l}327 \\
229 \\
110 \\
77 \\
22 \\
\end{array}$ & $\begin{array}{l}43 \\
30 \\
14 \\
10 \\
\mathbf{1 0} \\
\end{array}$ \\
\hline 5 & $\begin{array}{l}\text { Monthly Income } \\
\text { Less than Rs. } 25,000 \\
\text { Rs. 25,001 to Rs. 50,000 } \\
\text { Rs. 50,001 to Rs. } 75,000 \\
\text { Rs. 75,001 to Rs. 1,00,000 } \\
\text { Above Rs. 1,00,000 } \\
\end{array}$ & $\begin{array}{l}408 \\
168 \\
69 \\
46 \\
74 \\
\end{array}$ & $\begin{array}{l}53 \\
22 \\
09 \\
06 \\
10\end{array}$ \\
\hline 6 & $\begin{array}{l}\text { No. Of credit cards per person } \\
\text { None } \\
1 \\
2 \\
3 \\
4 \\
\end{array}$ & $\begin{array}{l}07 \\
463 \\
176 \\
85 \\
17\end{array}$ & $\begin{array}{l}01 \\
61 \\
23 \\
11 \\
02\end{array}$ \\
\hline
\end{tabular}




\begin{tabular}{|l|l|l|l|}
\hline & 5 & 09 & 01 \\
& More than 5 & 08 & 01 \\
\hline 7 & Family size & & \\
& 2 Members & 37 & 05 \\
& 3 Members & 142 & 19 \\
4 Members & 296 & 39 \\
& 5 Members & 158 & 21 \\
& 6 Members & $\mathbf{8 9}$ & 11 \\
& More than 6 & 43 & 05 \\
\hline
\end{tabular}

Table 2:- below indicates the descriptive analysis of the scores obtained of 765 respondents on 15 variables under study:

\begin{tabular}{|c|c|c|c|c|}
\hline \multirow[b]{2}{*}{ Sr. No. } & \multicolumn{4}{|l|}{ Descriptive Statistics } \\
\hline & Variables & Mean & $\begin{array}{c}\text { Std. } \\
\text { Deviation }\end{array}$ & $\begin{array}{c}\text { Coefficient } \\
\text { of } \\
\text { Variation }\end{array}$ \\
\hline 1 & Repairs and maintenance becomes difficult & 2.3966 & 1.07200 & 44.73003 \\
\hline 2 & Takes more delivery time & 2.6767 & 1.06237 & 39.68954 \\
\hline 3 & Complaints are not resolved immediately & 2.6008 & 1.07713 & 41.41533 \\
\hline 4 & Complaint procedures are lengthy & 2.5105 & 1.09743 & 43.7136 \\
\hline 5 & Complaints are not even listened sometimes & 2.6662 & 1.14132 & 42.80699 \\
\hline 6 & Sometimes get defective product & 2.4895 & 1.08783 & 43.69673 \\
\hline 7 & $\begin{array}{l}\text { Product design, size, shape and colour are different on website } \\
\text { but delivered product is not same }\end{array}$ & 2.6113 & 1.16048 & 44.4407 \\
\hline 8 & Online shopping procedure is difficult and cumbersome & 2.9215 & 1.12594 & 38.53979 \\
\hline 9 & $\begin{array}{l}\text { If electricity fails, whole procedure of shopping is to be done } \\
\text { again }\end{array}$ & 2.3979 & 1.03607 & 43.20739 \\
\hline 10 & $\begin{array}{l}\text { Sometimes transactions fail and money is deducted from our } \\
\text { account }\end{array}$ & 2.5746 & 1.07926 & 41.91952 \\
\hline 11 & Returns procedures are very lengthy & 2.5654 & 1.13084 & 44.08046 \\
\hline 12 & $\begin{array}{l}\text { Have to spend extra money (charges, postages etc.) if we want } \\
\text { to return the product }\end{array}$ & 2.7369 & 1.14145 & 41.70594 \\
\hline 13 & Getting refund becomes difficult & 2.5641 & 1.12511 & 43.87933 \\
\hline 14 & There are no stringent cyber laws in our country & 2.4699 & 1.30244 & 52.7325 \\
\hline 15 & It is hard to judge the quality of product & 2.2395 & 1.03868 & 46.38 \\
\hline
\end{tabular}

\section{Factor Analysis:-}

A technique of Factor analysis was applied to identify the barriers towards shopping online. In order to test the data appropriateness for factor analysis "KMO and Bartlett's Test" was carried out. A high value of KMO between 0.5 and 1.0, (Field, 2009. p. 647) suggests that the data is adequate for factor analysis. In this case the value was 0.934 which is closer to 1.0 and hence the data is fit for Factor analysis.

H0: There is no significant relationship between the variables in the population.

H1: There is a significant relationship between the variables in the population.

In order to test the null hypothesis Bartlett's Test of Sphericity was applied which showed that the significant value was 0.000 which is less than the 0.05 and hence the null hypothesis (H0) was rejected, approx chi-square value is 5183.164 which is also very large and hence it can be concluded that there is a significant relationship between the variables in the population or in other words the variables are highly correlated with each other. KMO value is 0.934 this testified that the sample was appropriate for factor analysis. 
Table 3:- KMO and Bartlett's Test.

KMO and Bartlett's Test

Kaiser-Meyer-Olkin Measure of Sampling Adequacy.

Bartlett's Test of Sphericity

\begin{tabular}{|l|l|}
\hline Approx. Chi-Square & 0.934 \\
\hline df & 5183.164 \\
\hline Sig. & 105 \\
\hline
\end{tabular}

The Kaiser-Meyer-Olkin (KMO) Measure of Sampling Adequacy is a statistic which indicates the proportion of variance in the variables that is common variance, i.e. which might be caused by underlying factors. High values (close to 1.0) generally indicate that a factor analysis may be useful with the given data. If the value is less than 0.50 , the results of the factor analysis probably won't be very useful. In this study the KMO measure is 0.934 thus confirming the appropriateness of Factor Analysis. Bartlett's test of sphericity indicates whether a given correlation matrix is an identity matrix, which would indicate that your variables are unrelated. The significance level gives the result of the test. Very small values (less than 0.05) indicate that there are probably significant relationships among given variables. A value higher than about .10 or so may indicate that the data are not suitable for factor analysis. In this case, the significance level has a very small value i.e. 0.000 which is less than 0.05 thus suggesting that the variables are highly correlated.

Table 4:- below indicates the Communalities obtained of 765 respondents on 15 variables under study:

\begin{tabular}{|c|l|c|c|}
\hline & \multicolumn{3}{|c|}{ Communalities } \\
\hline Sr. No. & \multicolumn{1}{|c|}{ Variables } & Initial & Extraction \\
\hline 1 & Repairs and maintenance becomes difficult & 1.000 & 0.383 \\
\hline 2 & Takes more delivery time & 1.000 & 0.611 \\
\hline 3 & Complaints are not resolved immediately & 1.000 & 0.670 \\
\hline 4 & Complaint procedures are lengthy & 1.000 & 0.646 \\
\hline 5 & Complaints are not even listened sometimes & 1.000 & 0.620 \\
\hline 6 & Sometimes get defective product & 1.000 & 0.486 \\
\hline 7 & $\begin{array}{l}\text { Product design, size, shape and colour are different on website but } \\
\text { delivered product is not same }\end{array}$ & 1.000 & 0.427 \\
\hline 8 & Online shopping procedure is difficult and cumbersome & 1.000 & 0.511 \\
\hline 9 & If electricity fails, whole procedure of shopping is to be done again & 1.000 & 0.444 \\
\hline 10 & Sometimes transactions fail and money is deducted from our account & 1.000 & 0.480 \\
\hline 11 & Returns procedures are very lengthy & 1.000 & 0.537 \\
\hline 12 & $\begin{array}{l}\text { Have to spend extra money(charges, postages etc.) if we want to return } \\
\text { the product }\end{array}$ & 1.000 & 0.509 \\
\hline 13 & Getting refund becomes difficult & 1.000 & 0.572 \\
\hline 14 & There are no stringent cyber laws in our country & 1.000 & 0.570 \\
\hline 15 & It is hard to judge the quality of product & 1.000 & 0.554 \\
\hline
\end{tabular}

\section{Communalities:-}

The communalities indicate how much of each variable accounted for by the underline factors taken together. A relatively high communality shows that not much of the variable is left over after whatever the factors represent is taken into consideration. Variable no. 03 has the highest communality of 0.670 which means that $67 \%$ of the variance or information content of this variable namely, "Complaints are not resolved immediately" is explained by the two factors taken together which is fairly good.

Principal component method was applied because the primary concern of this analysis was to determine the minimum number of factors that will account for maximum variance in the data. 
Extraction Method: Principal Component Analysis:-

Table 5:- Total Variance Explained: Extraction Method: Principal Component Analysis.

\begin{tabular}{|l|l|l|l|l|l|l|l|l|l|}
\hline \multirow{2}{*}{$\begin{array}{l}\text { Comp } \\
\text { onent }\end{array}$} & \multicolumn{2}{|l|}{ Initial Eigen values } & \multicolumn{2}{l|}{$\begin{array}{l}\text { Extraction Sums of Squared } \\
\text { Loadings }\end{array}$} & \multicolumn{2}{l|}{ Rotation Sums of Squared Loadings } \\
\cline { 2 - 10 } & Total & $\begin{array}{l}\text { \% of } \\
\text { Variance }\end{array}$ & $\begin{array}{l}\text { Cumulati } \\
\text { ve \% }\end{array}$ & Total & $\begin{array}{l}\text { \% of } \\
\text { Variance }\end{array}$ & $\begin{array}{l}\text { Cumu } \\
\text { lative } \\
\text { \% }\end{array}$ & Total & $\begin{array}{l}\text { \% of } \\
\text { Variance }\end{array}$ & $\begin{array}{l}\text { Cumulative } \\
\%\end{array}$ \\
\hline 1 & 6.888 & 45.923 & 45.923 & 6.888 & 45.923 & 45.923 & 4.794 & 31.963 & 31.963 \\
\hline 2 & 1.146 & 7.638 & 53.561 & 1.146 & 7.638 & 53.561 & 3.240 & 21.598 & 53.561 \\
\hline 3 & 0.901 & 6.008 & 59.570 & & & & & & \\
\hline 4 & 0.782 & 5.210 & 64.780 & & & & & & \\
\hline 5 & 0.761 & 5.071 & 69.850 & & & & & & \\
\hline 6 & 0.716 & 4.771 & 74.622 & & & & & & \\
\hline 7 & 0.580 & 3.868 & 78.489 & & & & & & \\
\hline 8 & 0.549 & 3.658 & 82.147 & & & & & & \\
\hline 9 & 0.483 & 3.218 & 85.365 & & & & & & \\
\hline 10 & 0.473 & 3.155 & 88.521 & & & & & & \\
\hline 11 & 0.400 & 2.664 & 91.185 & & & & & & \\
\hline 12 & 0.365 & 2.430 & 93.616 & & & & & & \\
\hline 13 & 0.342 & 2.281 & 95.897 & & & & & & \\
\hline 14 & 0.324 & 2.159 & 98.056 & & & & & & \\
\hline 15 & 0.292 & 1.944 & 100.000 & & & & & & \\
\hline Extraction Method: Principal Component Analysis. &
\end{tabular}

Table-5 helps explaining the extraction of two major factors highlighting the barriers customers' face towards online shopping along with their extracted cumulative percentage variances. The first panel in the above table gives values based on initial eigen values. For the initial solution, there are as many components or factors as there are variables. The "Total" column gives the amount of variance in the observed variables accounted for by each component or factor. The "\% of Variance" column gives the percentage of variance accounted for by each specific factor or component, relative to the total variance in all the variables. The "Cumulative \%" column gives the percentage of variance accounted for by all the factors or components up to and including the current one. In an appropriate factor analysis, there are few factors that explain a lot of variance and the rest of the factors explain relatively small amounts of variance. Therefore, all those remaining factors which account for a very small amount of cumulative variance can be left. In this study, first two components or factors as Eigen value for them is more than one (1) and account for a cumulative variance of $53.561 \%$ are taken and dropped remaining factors which account for only $46.439 \%$ of cumulative variance.

As the table shows, all the two factors jointly explain $53.56 \%$ of the total variance in the responses towards the variables on difficulties of online shopping. After reducing the 15 variables indicating the difficulties consumers face while shopping online into two (2) representative uncorrelated factors, regression analysis has been performed to identify those factors that highlight difficulties more. For regression analysis, Overall Consumer Satisfaction variable has been taken as dependent variable and the extracted two (2) factors as independent variables.

To determine the ratings of newly extracted factors, the original scores of initial variables (Product \& Services Reliability) correlated with their respective factors and have been averaged. For example, to find out ratings of the first factor i.e. Product \& Services Reliability the original ratings of all correlated variables (difficulties) such as Repairs and maintenance becomes difficult, Takes more delivery time, Complaints are not resolved immediately, Complaint procedures are lengthy, Complaints are not even listened sometimes, Sometimes get defective product, Product design, size, shape and colour are different on website but delivered product is not same, Online shopping procedure is difficult and cumbersome and Have to spend extra money(charges, postages etc.) if we want to return the product have been averaged. Similarly rests of the factor ratings have been calculated.

Varimax rotation was applied because the purpose was also to determine those factors which are uncorrelated with each other. The rotated component matrix is given in the Table- 6 below: 
Table 6:- Rotated Component Matrix.

\begin{tabular}{|c|l|c|c|}
\hline \multirow{2}{*}{ Sr. No. } & \multicolumn{1}{|c|}{ Rotated Component Matrix } & \multicolumn{1}{c|}{ Component } \\
\cline { 3 - 4 } & & \multicolumn{1}{|c|}{ Variables } & \multicolumn{1}{|c|}{$\mathbf{1}$} \\
\hline 1 & Repairs and maintenance becomes difficult & 0.584 & 0.206 \\
\hline 2 & Takes more delivery time & 0.755 & 0.201 \\
\hline 3 & Complaints are not resolved immediately & 0.793 & 0.202 \\
\hline 4 & Complaint procedures are lengthy & 0.756 & 0.273 \\
\hline 5 & Complaints are not even listened sometimes & 0.745 & 0.254 \\
\hline 6 & Sometimes get defective product & 0.662 & 0.218 \\
\hline 7 & $\begin{array}{l}\text { Product design, size, shape and colour are different on website but } \\
\text { delivered product is not same }\end{array}$ & 0.545 & 0.360 \\
\hline 8 & Online shopping procedure is difficult and cumbersome & 0.634 & 0.331 \\
\hline 9 & If electricity fails, whole procedure of shopping is to be done again & 0.266 & 0.611 \\
\hline 10 & Sometimes transactions fail and money is deducted from our account & 0.419 & 0.551 \\
\hline 11 & Returns procedures are very lengthy & 0.509 & 0.527 \\
\hline 12 & Have to spend extra money (charges, postages etc.) if we want to return & 0.518 & 0.491 \\
\hline 13 & Ge product & & \\
\hline 14 & There are no stringent cyber laws in our country & 0.407 & 0.637 \\
\hline 15 & It is hard to judge the quality of product & 0.077 & 0.751 \\
\hline
\end{tabular}

Extraction Method: Principal Component Analysis:-

Rotation Method: Varimax with Kaiser Normalization. Rotation converged in 3 iterations:-

The Factor analysis resulted in a total of two (2) factors that highlights the difficulties in shopping online. The Factors were named according to the variables that correlated within them. The following Table-7 shows the various factors that highlight the difficulties in shopping online along with the variables that correlate high with them, their factor loadings and their eigen values including the percentage of variance covered by each factor.

Table 7:- Factor Matrix

\begin{tabular}{|l|l|l|l|l|l|}
\hline $\begin{array}{l}\text { Factor } \\
\text { Number }\end{array}$ & $\begin{array}{l}\text { Factor } \\
\text { Name }\end{array}$ & Items & $\begin{array}{l}\text { Item } \\
\text { loading }\end{array}$ & Total & $\begin{array}{l}\text { \% of } \\
\text { Variance }\end{array}$ \\
\hline $\mathbf{1}$ & $\begin{array}{l}\text { Product \& } \\
\text { Services } \\
\text { Reliability }\end{array}$ & & 4.788 & 31.921 \\
\hline & & Repairs and maintenance becomes difficult & 0.584 & & \\
\hline & Takes more delivery time & 0.755 & & \\
\hline & Complaints are not resolved immediately & 0.793 & 0.756 & & \\
\hline & Complaint procedures are lengthy & 0.745 & & \\
\hline & Complaints are not even listened sometimes & 0.662 & & \\
\hline & Sometimes get defective product & 0.545 & & \\
\hline & $\begin{array}{l}\text { Product design, size, shape and colour are different } \\
\text { on website but delivered product is not same }\end{array}$ & & \\
\hline & $\begin{array}{l}\text { Online shopping procedure is difficult and } \\
\text { cumbersome }\end{array}$ & 0.634 & & \\
\hline $\mathbf{2}$ & $\begin{array}{l}\text { Have to spend extra money (charges, postages etc.) } \\
\text { if we want to return the product }\end{array}$ & 0.518 & & \\
\hline & $\begin{array}{l}\text { Technical } \\
\text { Aspects }\end{array}$ & $\begin{array}{l}\text { If electricity fails, whole procedure of shopping is to } \\
\text { be done again }\end{array}$ & 0.611 & & \\
\hline & Sometimes transactions fail and money is deducted & 0.551 & & \\
\hline & & & & \\
\hline
\end{tabular}




\begin{tabular}{|l|l|l|l|l|}
\hline & from our account & & & \\
\hline & Returns procedures are very lengthy & 0.527 & \\
\hline & Getting refund becomes difficult & 0.637 & & \\
\hline & There are no stringent cyber laws in our country & 0.751 & & \\
\hline & It is hard to judge the quality of product & 0.718 & & \\
\hline
\end{tabular}

In order to identify the most contributing factor affecting overall satisfaction of online shoppers, multiple regression analysis was carried out between the overall satisfaction level (dependent variable as measured on the fivepoint scale) and extracted factor scores as independent variables. The results of regression analysis are summarised in the table below:

Regression Analysis:-

Table 8:- (Results of Regression Analysis)

\begin{tabular}{|c|c|c|c|c|c|c|}
\hline & B & Std. Error & Beta & $\mathrm{t}$ & Sig. \\
\hline \multirow{2}{*}{\multicolumn{2}{|c|}{$\begin{array}{l}1 \\
\text { (Constant) }\end{array}$}} & 2.175 & 0.027 & & 80.288 & 0.000 \\
\hline & & -0.116 & 0.027 & -0.151 & -4.273 & 0.000 \\
\hline $\begin{array}{l}\text { Regression factor score } \\
\text { for analysis } 1 \\
\text { Regression factor score } \\
\text { for analysis } 1\end{array}$ & 1 & -0.128 & 0.027 & -0.166 & -4.704 & 0.000 \\
\hline
\end{tabular}

Predictors: Product \& Services Reliability and Technical Aspects

Dependent Variable: Overall satisfaction from online shopping

The above table shows that the estimated regression model can be presented as:-

Overall Satisfaction $=2.175-0.116 *$ Product \& Services Reliability $-0.128 *$ Technical Aspects

Thus "Technical Aspects" is a major contributing factor to the overall satisfaction level which implies that the major difficulties faced by the online shoppers are regarding technical and procedural aspects of online shopping.

$\mathrm{R}$ squared is the proportion of variation in the dependent variable explained by the regression model. The values of $\mathrm{R}$ squared range from 0 to 1 . Small values indicate that the model does not fit the data well. The sample $\mathrm{R}$ squared tends to optimistically estimate how well the model fits the population. For the above data, $\mathrm{R}$ squared value is .050 which is very low indicating very weak relationship between the extracted factor scores and overall satisfaction of the online shoppers, which implies that several other factors which affect the online shopper's overall satisfaction are not revealed through this study. This may deal with some other factors such as price, convenience, product variety, product information; customised offers may be more contributing factors to their overall satisfaction rather than difficulties faced by them while shopping online.

\section{Conclusion:-}

In India, research figures by BCG says that in the year 2014, $70 \%$ of rural people and $40 \%$ urban people use internet on mobile phones but if we see the Ecommerce market, it was just \$ 17 Billion. If this is the access rate we can see the difference between the penetration rate of Internet and penetration rate of Ecommerce. If we compare this with China, we lag behind 6 to 7 years in the penetration rate of ecommerce. This study tried to find out what difficulties people face when they shop online when the number of internet users is so high compared to the Ecommerce users. The study is an eye opener to online shopping companies. The study revealed that people who shop online face some Product \& Services related problems and some Technical problems. The online retailers should take care of delivering exactly what is ordered by the customers with a sound, fast and easy Complaint \& Return Procedures to increase the online business and give maximum satisfaction to customers at the same time it throws light on the weaknesses of legal system and other infrastructure facilities. The policy makers should try to make stringent cyber laws and infrastructure facilities should be improved so that the rate of E-commerce can be enhanced. 


\section{References:-}

1. Huizingh \& Hoekstra, (2003) Journal of Targeting, Measurement and Analysis for Marketing Vol. 11, 4, 350361 Henry Stewart Publications 0967-3237

2. Katawetawaraks, C., \& Cheng, L. W. (2011). Online shopper behaviour: Influences of online shopping decision. Asian Journal of Business Research, 1(2).

3. Ma De Swardt - 2008 - "Factors influencing the choice to shop online under south African context" repository.up.ac.za

4. Maignan. I and Lukas. BA, the nature and social uses of the internet: a qualitative investigation. Journal of Consume Affairs, Vol. 31, No.2, 346-71, 1997.

5. Punyani, G., Sharma, S., \& Dash, G. (2015). Examining Factors Affecting Females 'perception Towards The Usage Of Electronic Payment System: An Exclusive Study On E Shopping. Management, 1(3), 275-288.

6. Renouf, M., \& Maniglier, S. (2013). Main factors influencing online consumer behaviour changes.

7. Singla B.B., Pawan Kumar (2011), "E- Shopping: A Shift From Marketplace To Market Space" IJRIME Volume 1 Issue 3 ISSN:

8. Sultan, M. U., \& Uddin, M. (2011). Consumers' Attitude towards Online Shopping: Factors influencing Gotland consumers to shop online.2249- 1619

9. Virdi S, Puri, Modi and Sehgal (2007); Pragmatic Buyers or Browsers? A study of online buying behaviour. Journal of Indian Management Studies Vol II pp141-166

10. Y J Lee, CL Huang, L Y Chang, C Y Chen, 'Exploring the Influence of Online Consumers' Perception on Purchase Intention as Exemplified with an Online Bookstore". Journal of Global Business Management, 2009

11. Zheng, F. (2006). Internet Shopping and Its Impact on Consumer Behaviour. University of Nottingham. 